\title{
Value Relevance of Intangible Assets Before and After FRS 138 Adoptions: Evidence From Malaysia
}

\author{
Nik Azmiah Binti Nik Azin ${ }^{1} \&$ Norhayati bt Alias ${ }^{1}$ \\ ${ }^{1}$ Faculty of Accountancy, Universiti Teknologi MARA, Malaysia \\ Correspondence: Norhayati bt Alias, Lecturer at Faculty of Accountancy, Universiti Teknologi MARA, Malaysia.
}

Received: April 20, 2019

Accepted: May 7, 2019

Online Published: May 19, 2019

doi:10.5430/ijfr.v10n3p267

URL: https://doi.org/10.5430/ijfr.v10n3p267

\begin{abstract}
The economic environment has changed from the era of agriculture, industrial and now to an information era. In this information era, intangible assets dominate the environment compared to during industrial era that was mainly dominated by tangible assets. Intangible asset plays an important role in today's economy with the shift from being an industrialised economy to a high-tech and service-oriented. In Malaysian capital market, there is an upward trend of intangible assets development. Hence, the question of whether the value relevance of intangible assets is properly reflected in financial statements arises. The objective of this study is to examine the value relevance of intangible assets in Malaysia before and after the adoption of FRS 138. This study used a sample of 113 public listed companies from four main sectors namely Industrial Product, Trading services, Consumer Product and Technology. The period under study was divided into two, that is, pre adoption period (2002-2005) and post adoption period (2008-2011) to observe if there were any improvements on the value relevance of intangible assets after the adoption of International Financial Reporting Standards (IFRS). The data was analysed to examine the value relevance of intangible assets in Malaysia before and after the adoption of FRS 138. The finding of this study suggests that intangible assets are value relevant in the pre adoption period but are not value relevant in the post adoption period. This study may contribute to the existing literature on the economic consequences of adopting IFRS and also preliminary indication of the impact of FRS 138 adoption.
\end{abstract}

Keywords: value relevance, intangible asset, firms' performance, pre and post, FRS138

\section{Introduction}

As the economic environment changes to become more global, the way and nature of the investments being made domestically and internationally also change over the time. A major challenge in this environment is to ensure that relevant information is provided through a reporting for the internal management as well as financial reporting to external parties (Matolcsy, Stokes, \& Wells, 2002; Fitriandi., Kakinaka \& Kotani, 2014; Aremu \& Ediagbonya, 2018; Okafor and Shaibu, 2016; Mokuolu, 2018; Khemili and Belloumi, 2018). The economic environment has also changed from the era of agriculture, industrial and now to an information era. In this information era, intangible assets dominate the environment compared to during industrial era that was dominated by tangible assets (Abubakar, 2015; Zhang, 2018; Okon and Monday, 2017; Edeme, 2018; Almeqdadi, 2018; Setiyawati, et.al. 2018). These changes have led the role of intangibles to increase to provide a more informative and reflective business performance intended for the investors in the decision-making process which the traditional accounting standards cannot fulfil anymore (Istrate, 2013; Ibrahim and Ali, 2014; Sarwar and Mubarik, 2014; Okoye, 2014; Wilson, et.al. 2014; Chidoko, 2014; Ekpung, 2014; Kasasbeh, et.al. 2018; Hawamdeh, 2018; Yu-Chi and Lin, 2018).

The focus of the area of study in this paper is on Financial Reporting Standard (FRS) 138 which cover the intangible assets treatment. In the case of Malaysia, The International Accounting Standard (IAS) 38 on intangible asset was not previously adopted by Malaysia as reported by (Abdul-Shukor, Ibrahim, \& Kaur, 2008). Malaysia only adhered to the move in 2005. Malaysian Accounting Standard Board (MASB) defines Malaysian Financial Reporting Standards (MFRS) 138 as "an identifiable non-monetary asset without physical substance held for use in the production or supply of goods or services, for rental to others, or for administrative purposes". As such, the objective of this study is to examine the value relevance of reported intangible asset in Malaysia before and after the adoption of FRS 138. The question that this study need to look into and answered is has the value relevance of intangible assets changed after IFRS adoption and is there a significant relationship between value relevance of 
intangible assets with a firm's performance.

The period of this study is divided into two parts which include a period before (pre) the after (post) adoption of the FRS 138. Analysis will be carried out between year 2002 to 2005 for pre adoption period and year 2008 to 2011 for post adoption period. Since the standard for FRS 138 applies for the company having annual reporting period beginning on or after 1 Jan 2006, this study has excluded data for the year 2006 and 2007 to allow for a transitional effect. This study only focuses on Malaysian public listed companies which have the same financial year ending in 31 December. The list of these Malaysian companies was obtained from Bursa Malaysia website (www.bursamalaysia.com.my) of public listed companies under the Main Market. The industry sector that was selected comprises of Industrial Product, Consumer Product, Technology and Trading Services.

The next section of this paper presents literature review, underpinning theoretical perspective and development of hypotheses. Section three explained the methodology adopted by this study. Section four discusses on the findings, analysis and discussions. Chapter Five concludes this paper

\section{Literature Review and Hypotheses Development}

\subsection{Intangible Asset}

The importance of intangible asset has been changed by what is happening now in the new economy with global influence of information. Ciprian, Valentin, Mădălina, \& Lucia (2012) in their study have mentioned that the growing importance of intangible asset can be seen through the percentage of the intangible asset with total assets. In 1978, it can be seen that intangible assets constituted 5\% of asset. In 1998, it can be seen that intangible assets constituted $72 \%$ of assets and today, almost $75 \%-85 \%$ of assets are intangible. Some of the intangible assets is not reflected or presented in a firm's financial statements. This is because of the difficulties to be quantified or measured in terms of monetary value (Gamayuni, 2015). According to Istrate (2013), there is no general classification of intangible assets, hence, many researchers have made their own classification.

\subsection{Accounting for Intangible Assets in Malaysia}

In the pre adoption period of FRS, intangible asset was covered under MASB Approved Accounting Standard 4 that is accounting for all activities that relates to Research and Development. MASB 4: Research and Development costs were brought into effect commencing 1 July 1999 and later were renamed as FRS 109 in 2004. During that period a specific accounting standard for intangible asset was absent. Even though standard for IAS 38 that talks about intangible assets being issued by the International Accounting Standards Board (IASB) in 1998, somehow Malaysia did not adopt the standard (Jaafar \& Halim, 2013). Towards the move for the adoption of International Financial Reporting Standards (IFRS) in Malaysia, MASB has adopted FRS 138 Intangible Asset (a modified version of IAS 38) in 2005 and has taken effect for the period beginning on or after 1 January, 2006. This standard prescribed the company treatment on intangible asset, which is it determines the criteria for their recognition, defines measurement of book value and specify the requirement on disclosures on intangible asset (Krstić \& Đorđević, 2010). MASB 4 Research and Development Costs standard and MASB 21 Business Combinations standard are the standards on intangible assets applicable in Malaysia before the adoption of FRS 138 in 2006 (Jaafar \& Halim, 2013). IAS 38 also provides guidelines for all other identifiable intangibles' asset other than goodwill and R\&D expenditures on their accounting treatment. Major changes in the Malaysian accounting practices for these assets are being seen resulting from this implementation (Jaafar \& Halim, 2013). This is because in the pre-IFRS, there was no specific standard for intangible assets. This standard is applied for the company having a yearly reporting periods beginning on or after 1 January 2006.

\subsection{Intangible Assets Value Relevancy After IFRS Adoption}

Kargin (2013) has stated that value relevance can be defined as the ability of information that is presented by financial statements to capture and summarise a firm's value. There are few studies that have been done to examine intangible assets value relevancy in the post IFRS adoption period. Ji \& Lu (2014) have done a study to examine the intangible assets value relevancy in the pre and post adoption period of IFRS for Australian listed firms. The study has also investigated whether the value relevance of intangible asset was associated with its value reliability. Furthermore, the study was also intended to report whether adoption of IFRS could improve the value relevance of intangible assets and alter the relationship between value relevance and reliability. The results from the study have shown that intangible assets that has been capitalised were value relevant in the both pre- and posts IFRS adoptions. Firms with more reliable information on intangible asset will be having higher value relevance. However, the study found that the value relevance of intangibles declined in the post adoption period. Nevertheless, the study also shows that there was a positive relationship between the value relevance and the reliability of intangibles and it remained 
unchanged in the post adoption period. Similar results have also been found by Istrate (2013) in the study that was aimed to examine the goodwill and other intangible assets in terms of its value relevance in the pre adoption period as well as post adoption periods of IFRS over UK companies. The study shows that in the post adoption period of IFRS, there is no increase in the value relevance of goodwill and other intangible assets. However, the goodwill and other intangible assets are significantly related with market value.

In contrast, a study by Jaafar \& Halim (2013) which examined the relationship between intangible assets choice of accounting and their value relevance before and after FRS138 adoption for Malaysian companies have found that for the period of the pre IFRS adoption, identifiable intangible assets that has been capitalised are being regarded by as value relevant by the Malaysian market. However, the findings do not support the author's prediction that the value relevance of capitalise intangible assets is higher during the pre IFRS periods as compared to the post IFRS period. Results have shown that in the period post IFRS, the value relevance of intangible assets was actually higher, hence, indicated that after the new accounting standards has been introduced for intangible assets, higher value relevance for intangible assets has been attached by the Malaysian market. Another study was conducted by Kargin (2013) to investigate accounting information value relevancy for Turkish listed firms in the pre IFRS and post IFRS application from the year 1998 to the year 2011. The study also explored the impact of IFRS adoption on the book value relevance and earnings relevance for stock valuation in Istanbul Stock Exchange. The author opined that decision makers expected that the accounting information which was reflected in the financial statement to be useful. Results from the study show that the value relevance of accounting information has improved in the post IFRS period. Furthermore, the results also show that the overall book value is value relevant in determining market value or stock prices.

\subsection{Underpinning Theoretical Perspective}

The underpinning theoretical perspective of this study is based on the Agency Theory. According to Company, Jensen, \& Meckling (1976) have defined agency relationship as a contract under which one or more people (the principal(s)) engage with another person (the agent) to perform some kind of service on their behalf which involves delegating some decision-making authority to the agent. Their research was confined to a small general problem that is the analysis of agency cost generated by the contractual arrangement between the owners and top managements of the company. As viewed by Jerzemowska (2006) and according to the theory of the relationship between principals (owners) and agents (managers) - principal-agent theory - owners would hire managers to run the firm on their behalf. However, the aim of the principals (owners) and the aim of the agents (managers) were not consistent. The owners' aim was to maximize the market value which was not in sequence with the managers. Managers prefer to maximise their own personal interest, even at the expense of the firms' owners (Jerzemowska, 2006).

Another theory that is related to this study is the signalling theory. Signalling theory originally developed to explain the information asymmetry in labour market Spence, (1973) and it addresses this problem (i.e. information asymmetry) in the market (Morris, 1987). According to Morris, (1987) signalling theory shows that the information asymmetry can be reduced by the party with more information signalling it to others. This theory gives an idea to ensure that the capital market does not undervalue firms in their decision-making (Abdul-Shukor et al., 2008). The theory suggests accounting information that is being reported will show any actions that have been taken by the managers, hence providing the capital markets with the signals. Abdul-Shukor et al. (2008) have indicated that intangibles that are being reported and any intangible changes should be able to signal the firm's true position relating to its intangible's issues. In this signalling theory, one can interpret that the manager is more willing to increase the company market value for their own benefit (Widiantoro, 2012). The market will lower down the firms' share market prices if they realise that the firms have been providing wrong signals to the market. According to (Shukor, Ibrahim, Kaur, \& Nor, 2009) information can be linked towards the value relevance concept base on the availability of signals from intangible noncurrent asset.

\subsection{Development of Hypothesis}

The focus on the development of hypothesis is to answer the research questions asked in this study that is whether and what extent has the value relevance of intangible assets changed after the adoption of IFRS. Since this study focuses on two different accounting scenarios, the hypothesis has been separated into two distinct periods, namely pre adoption period of FRS 138 and post adoption period of FRS 138. For the purpose of hypothesis development, its significant relationship with firm's performance provides evidence on the existence of value relevance in intangible Non-Current Asset.

FRS adoption effects relating to intangible assets are depending on either one or more key factors. Chalmers \& Godfrey (2006) has identified key factors in their study for the Australian Equivalent of International Financial 
Reporting Standards (AIFRS) adoption, that is its included (i) reported balance of the intangible asset holdings by the firms' prior to AIFRS adoption (ii) accounting policies adopted by the firms before the AIFRS adoption and (iii) the induced effects in anticipating or reaction to AIFRS adoption whereby possibility firms' make changes to financing, operating, or investment strategies. As mentioned by Abdul-Shukor et al. (2008), the aimed of accounting standards present is to assist the preparers of financial statement and the accountants in reporting and presenting accounting information that is more reliable and relevance. In this case, the information available on intangible assets is expected to be more reliable and relevant.

An association between Intangible Assets and performance still stands ambiguous (Bhatia \& Aggarwal, 2018). This can be seen from prior literature on the impact of intangible assets on performance which have found a positive impact of intangible on performance (Bhatia \& Aggarwal, 2018; Gamayuni, 2015; Haji \& Ghazali, 2018), while few others have found that the impact of intangible on performance was negative (Ruiwen \& Honghui, 2010; Widiantoro, 2012). The following proposed hypotheses were developed after above discussions as below;

- H1- Intangible assets are value relevant in the pre adoption period of FRS138

- $\quad$ H2- Intangible assets are value relevant in the post adoption period of FRS138

\section{Research Methodology}

Secondary data was collected from audited annual reports of companies extracted from the main market of Bursa Malaysia, Thompson One and respective companies' websites. Research samples were selected using simple random sampling for companies having financial year end of 31 December. Period was divided into two, the pre adoption period (year 2002to 2005) and post adoption period (year 2008 to 2011). Period from year 2006 to 2007 was not considered to allow for transition period years and to allow the effect of (IFRS) implementation on the reporting of intangible assets (Jaafar \& Halim, 2013). Table 1A shows the sample selection process and Table 1B shows final sample data according to the industries.

Table 1A. Sample selection

\begin{tabular}{lll}
\hline Sample selection & Companies & Firm-years \\
\hline 1. Coverage 2002-2005 and 2008-2011 & 564 & 4512 \\
\hline $\begin{array}{l}\text { 2. Companies being removed due to FYE not on 31 } \\
\text { December }\end{array}$ & 240 & 1920 \\
$\begin{array}{l}\text { 3. Companies being removed due to the following reasons; (i) } \\
\text { have no annual report during pre adoption period (ii) have } \\
\text { changes on FYE date (iii) have no data or missing data }\end{array}$ & 211 & 1688 \\
\hline FINAL sample & 113 & 904 \\
\hline
\end{tabular}

Table 1B. Number of companies

\begin{tabular}{ll}
\hline Sectors & Number of Companies \\
\hline Industrial Product & 47 \\
\hline Trading Services & 39 \\
\hline Consumer Product & 22 \\
\hline Technology & 5 \\
\hline Total sample size & $\mathbf{1 1 3}$ \\
\hline
\end{tabular}

\subsection{Model and Measurement of Variables}

Price Model can be used for firms valuation at one point in time (Easton, Eddey, \& Harris, 1993), hence this study was tested using the Price model. Price model used for this study was adopted from Abdul-Shukor et al. (2008). The author develops the designed model for the empirical framework based on the understanding of the accounting information decision usefulness paradigm (Abdul-Shukor et al., 2008). As suggested by decision usefulness paradigm, if the reported intangible Non-Current Asset is significantly associated with firms value, it will have value 
relevance, as mentioned by Scott, (2000) cited in (Shukor et al., 2009), which in this study is being represented by firms' share market price. The price model (Figure 1) has a dependant variable (DV) which is $\mathrm{P}$ and an independent variables (IV) which are INCA, FNCA, IVNCA, IPNCA, CA, TL and EARN. For this study, the data on IPNCA was not included for analysis as this study replicates the study from (Abdul-Shukor et al., 2008) which excludes data on IPNCA. As such, in this study, the property industry was not examined. This leads to the final Price Model as per Figure 1 and the summary of variables as per Teble 2 .

\section{$P_{i t}=\lambda_{0}+\lambda_{1} I N C A_{i t}+\lambda_{2} F_{N C A}+\lambda_{3} I V N C A_{i t}+$ $\lambda_{5} \mathrm{CA}_{\mathrm{it}}+\lambda_{6} \mathrm{TL}_{\mathrm{it}}+\lambda_{7} \mathrm{EARN}_{\mathrm{it}}+\varepsilon_{\mathrm{it}}$}

Figure 1. Price model

Table 2. Variables

\begin{tabular}{ll}
\hline Dependent Variable & \\
\hline Pit & Firm i per share market price at time t (fiscal year-end). \\
\hline Independent Variable & \\
\hline INCAit & Book value of intangible NCA reported at year-end per share for firm i at time t \\
\hline FNCAit & $\begin{array}{l}\text { Book value of fixed asset or property, plant, and equipment reported at year-end } \\
\text { per share for firm i at time t. }\end{array}$ \\
\hline IVNCAit & Book value of investments reported at year-end per share for firm i at time t. \\
\hline CAit & Book value of current assets reported at Year-end per share for firm i at time t. \\
\hline TLit & Book value of total liabilities reported at Year-end per share for firm i at time t. \\
\hline EARNit & Earnings (reported) before extraordinary items per share for firm i at time t. \\
\hline Eit & Error term represented in this regression \\
\hline
\end{tabular}

\section{Findings, Analysis and Discussion}

\subsection{Descriptive Analysis}

Table 3A and Table 3B below showed that under the study period, the selected variables for sample data period from year 2002 to 2005 have shown positive means that range from 1.34 for Price (variable P) to 0.12 for Earnings (variable EARN). As for the selected variables for sample data period from year 2008 to 2011, they also have shown positive mean ranging from 1.34 for Current Asset (variable CA) to 0.12 for Earning (variable EARN) respectively.

Statistics of variables for sample data during pre adoption period (year 2002 to 2005) were provided in Table 3A and statistics of variables for sample data during post adoption period (year 2008 to 2011) were provided in Table 3B. Market price per share (variable P) has shown a higher mean during pre adoption period at 1.34 (Table 3A) compared to a slight reduction of the mean score during post adoption period at 1.33 (Table 3B). The median values for $\mathrm{P}$ were 1.37 during pre and remains same during post adoption period. Mean values of FNCA ( 0.97 during pre adoption period, 0.91 during post adoption period), IVNCA (0.24 during pre adoption period, 0.21 during post adoption period), CA (1.36 during pre adoption period, 1.34 during post adoption period) and TL (1.13 during pre adoption period, 1.09 during post adoption period) have shown similar trends of higher amount during pre adoption period. On the other hand, INCA ( 0.19 during pre adoption period, 0.21 during post adoption period) have shown a lower amount during pre adoption period for the sample data of this study. However, variable EARN (0.12 during pre adoption period, 0.12 during post adoption period) remains same pre and post adoption period.

The highest standard deviation during pre adoption period was from variable $\mathrm{P}$ at 2.13 and the least was from variable EARN at 0.19 as shown in Table 3A. Similarly, in Table 3B, the highest standard deviation during post adoption period was from variable $\mathrm{P}$ at 2.17 and the least was from variable EARN at 0.19 . Table $3 \mathrm{~A}$ and $3 \mathrm{~B}$ revealed that the sample data for both pre and post adoption period are having a lower or small deviation from the mean, that is, during pre and post adoption period standard deviation for variable INCA is at 0.43 for pre and 0.40 for 
post, FNCA at 1.32 for pre and 1.30 for post, IVNCA at 0.84 for pre and 0.89 for post, CA at 1.22 for pre and 1.23 for post, TL at 1.34 for pre and 1.33 for post. A low standard deviation means that most of the numbers are very close to the average.

Table 3A. Descriptive statistics on variables, data sample for year 2002 to year 2005 (pre adoption period)

\begin{tabular}{llllll}
\hline & Mean & Median & Std Dev & Min & Max \\
\hline $\mathrm{P}$ & 1.34 & 1.37 & 2.13 & -4.03 & 6.35 \\
\hline INCA & 0.19 & 0.17 & 0.43 & -0.46 & 1.29 \\
\hline FNCA & 0.97 & 0.96 & 1.32 & -2.37 & 4.34 \\
\hline IVNCA & 0.24 & 0.22 & 0.84 & -0.51 & 2.45 \\
\hline CA & 1.36 & 1.36 & 1.22 & -1.70 & 4.19 \\
\hline TL & 1.13 & 1.17 & 1.34 & -2.22 & 4.61 \\
\hline EARN & 0.12 & 0.12 & 0.19 & -0.37 & 0.57 \\
\hline
\end{tabular}

$\mathrm{N}=113$

Table 3B. Descriptive statistics of variables, data sample for year 2008 to year 2011 (post adoption period)

\begin{tabular}{llllll}
\hline & Mean & Median & Std Dev & Min & Max \\
\hline $\mathrm{P}$ & 1.33 & 1.37 & 2.17 & -4.03 & 6.35 \\
\hline INCA & 0.21 & 0.20 & 0.40 & -0.28 & 1.17 \\
\hline FNCA & 0.91 & 0.93 & 1.30 & -2.37 & 3.97 \\
\hline IVNCA & 0.21 & 0.19 & 0.89 & -2.31 & 2.57 \\
\hline CA & 1.34 & 1.34 & 1.23 & -1.70 & 4.19 \\
\hline TL & 1.09 & 1.08 & 1.33 & -2.22 & 3.99 \\
\hline EARN & 0.12 & 0.12 & 0.19 & -0.32 & 0.62 \\
\hline
\end{tabular}

$\mathrm{N}=113$

\subsection{Normality Test}

A basic assumption test was conducted to qualify for regression tests such as normality and multicollinearity test. To account for the non normality of data, the data has been transformed using A Two-Step Approach for transformation (Templeton \& Templeton, 2011). Once data has been completely transformed, a normality test was carried out using the Skewness and Kurtosis. Table 4A and Table 4B shows that the data used in this study are normally distributed. Following this conclusion, this study used parametric statistical tools for further analysis.

Table 4A. Summary statistics of skewness and kurtosis for sample data period for year 2002 to year 2005 (pre adoption period)

$\mathrm{N}=113$

\begin{tabular}{llll}
\hline & Skewness & Kurtosis & Distribution \\
\hline $\mathrm{P}$ & -0.086 & -0.245 & Normal \\
\hline INCA & 0.240 & -0.562 & Normal \\
\hline FNCA & 0.045 & -0.162 & Normal \\
\hline IVNCA & 0.666 & -0.746 & Normal \\
\hline CA & -0.048 & -0.301 & Normal \\
\hline TL & -0.056 & -0.233 & Normal \\
\hline EARN & -0.010 & -0.370 & Normal \\
\hline
\end{tabular}

\section{$N=113$}


Table 4B. Summary statistics of skewness and kurtosis for sample data period for year 2008 to year 2011 (post adoption period)

\begin{tabular}{llll}
\hline & Skewness & Kurtosis & Distribution \\
\cline { 2 - 5 } P & -0.043 & -0.367 & Normal \\
\hline INCA & 0.297 & -0.864 & Normal \\
\hline FNCA & -0.069 & -0.274 & Normal \\
\hline IVNCA & 0.372 & -0.322 & Normal \\
\hline CA & -0.021 & -0.336 & Normal \\
\hline TL & -0.052 & -0.411 & Normal \\
\hline EARN & 0.070 & -0.291 & Normal \\
\hline
\end{tabular}

$\mathrm{N}=113$

\subsection{Pearson Correlation}

This study has performed the Pearson Correlation coefficient in order to test the correlation of each variable that was, between the DV and the IV. The relationship between INCA and P was investigated using Pearson Correlation Coefficient. A guideline provided by Cohen, 1998 cited in (Pallant, 2007) has recommended that if $r=0.10$ to 0.29 or $\mathrm{r}=-0.10$ to -0.29 , it indicates small correlation. If $\mathrm{r}=0.30$ to 0.49 or -0.30 to -0.49 , it indicates medium correlation and if $\mathrm{r}=0.50$ to 1.0 or -0.50 to -1.0 , it indicates a large correlation. During pre adoption period (Table $5 \mathrm{~A}$ ) there was a medium, positive and significant correlation between INCA and $\mathrm{P}$ with $\mathrm{r}=0.405, \mathrm{n}=113, \mathrm{p}=0.000$. There was an interesting finding with regards to post adoption period (Table 5B) where there was a small, positive and insignificant correlation between INCA and $\mathrm{P}$ with $\mathrm{r}=0.073, \mathrm{n}=113, \mathrm{p}=0.441$. The above findings have supported $\mathrm{H} 1$ but differed from the expectation in $\mathrm{H} 2$.

Another finding is concerning variable FNCA, IVNCA, CA, TL and EARN correlation with P. While there is significant relationship between the variables during both pre and post adoption period but the relationship has become weaken post adoption period. For FNCA, r-value is 0.631 during the pre adoption period and is significant $(\mathrm{p}=0.000)$ and $\mathrm{r}$-value is 0.478 during the post adoption period and is significant $(\mathrm{p}=0.000)$. For IVNCA, $\mathrm{r}$-value is 0.405 during the pre adoption period and is significant $(\mathrm{p}=0.000)$ and $\mathrm{r}$-value is 0.349 during post adoption period and is significant $(\mathrm{p}=0.000)$. For CA, $\mathrm{r}$-value is 0.717 during pre adoption period and is significant $(\mathrm{p}=0.000)$ and $\mathrm{r}$-value is 0.593 during post adoption period and is significant $(\mathrm{p}=0.000)$. For $\mathrm{TL}, \mathrm{r}$-value is 0.580 during pre adoption period and is significant $(\mathrm{p}=0.000)$ and $\mathrm{r}$-value 0.363 during post adoption period and is significant $(\mathrm{p}=0.000)$. For EARN, $\mathrm{r}$-value is 0.733 during pre adoption period and is significant $(\mathrm{p}=0.000)$ and $\mathrm{r}$-value 0.576 during post adoption period and is significant $(\mathrm{p}=0.000)$. A multiple regression analysis was then performed to test the association between intangible assets and share market price.

Table 5A. Pearson correlations of variables for sample data period for year 2002 to year 2005 (pre adoption period)

\begin{tabular}{llllllll}
\hline & $\mathrm{P}$ & INCA & FNCA & IVNCA & CA & TL & EARN \\
\hline P & 1.000 & & & & & & \\
\hline INCA & $0.405^{* *}$ & 1.000 & & & & & \\
\hline FNCA & $0.631^{* *}$ & $0.248^{* *}$ & 1.000 & & & & \\
\hline IVNCA & $0.405^{* *}$ & $0.247^{* *}$ & $0.346^{* *}$ & 1.000 & & & \\
\hline CA & $0.717^{* *}$ & $0.306^{* *}$ & $0.614^{* *}$ & $0.300^{* *}$ & 1.000 & & \\
\hline TL & $0.580^{* *}$ & $0.427^{* *}$ & $0.733^{* *}$ & $0.342^{* *}$ & $0.752^{* *}$ & 1.000 & \\
\hline EARN & $0.733^{* *}$ & $0.283^{* *}$ & $0.387^{* *}$ & $0.354^{* *}$ & $0.531^{* *}$ & $0.310^{* *}$ & 1.000 \\
\hline
\end{tabular}

**. Correlation is significant at the 0.01 level (2-tailed). 
Table 5B. Pearson correlations of variables for sample data period for year 2008 to year 2011 (post adoption period)

\begin{tabular}{llllllll}
\hline & $\mathrm{P}$ & INCA & FNCA & IVNCA & CA & TL & EARN \\
\hline $\mathrm{P}$ & 1.000 & & & & & & \\
\hline INCA & 0.073 & 1.000 & & & & & \\
\hline FNCA & $0.478^{* *}$ & 0.161 & 1.000 & & & & \\
\hline IVNCA & $0.349^{* *}$ & 0.132 & $0.242^{* *}$ & 1.000 & & & \\
\hline CA & $0.593^{* *}$ & $0.213^{*}$ & $0.497^{* *}$ & $0.306^{* *}$ & 1.000 & & \\
\hline TL & $0.363^{* *}$ & $0.262^{* *}$ & $0.775^{* *}$ & $0.246^{* *}$ & $0.688^{* *}$ & 1.000 & \\
\hline EARN & $0.576^{* *}$ & -0.009 & 0.081 & $0.340^{* *}$ & $0.317^{* *}$ & -0.071 & 1.000 \\
\hline
\end{tabular}

**. Correlation is significant at the 0.01 level (2-tailed); *. Correlation is significant at the 0.05 level (2-tailed).

\subsection{Multicollinearity Test}

This study has produced the multicollinearity test to observe the strength of correlation between two or more independent variables. A detecting technique of Tolerance level and Variance inflation factor (VIF) is being adopted to detect the presence of multicollinearity. Table $6 \mathrm{~A}$ and Table $6 \mathrm{~B}$ present the test results. If the value of tolerance is less than 0.2 or 0.1 and the VIF factor is 10 and above, then the multicollinearity will be problematic. From the test results, multicollinearity was not a problem in this study as the value of tolerance for all the variables was more than 0.2 and the value of VIF for all variables was less than 10 (Table 6A and Table 6B).

Table 6A. Multicollinearity test: Tolerance and Variance Inflation Factor (VIF) pre adoption period of FRS 138

\begin{tabular}{lll}
\hline & Tolerence & VIF \\
\hline INCA & 0.757 & 1.322 \\
\hline FNCA & 0.420 & 2.381 \\
\hline IVNCA & 0.799 & 1.252 \\
\hline CA & 0.329 & 3.040 \\
\hline TL & 0.253 & 3.947 \\
\hline EARN & 0.596 & 1.678 \\
\hline
\end{tabular}

a. Dependent Variable: NormPre.pri

Table 6B. Multicollinearity test: Tolerance and Variance Inflation Factor (VIF) post adoption period of FRS 138

\begin{tabular}{lll}
\hline & Tolerence & VIF \\
\hline INCA & 0.920 & 1.087 \\
\hline FNCA & 0.361 & 2.773 \\
\hline IVNCA & 0.807 & 1.240 \\
\hline CA & 0.373 & 2.682 \\
\hline TL & 0.204 & 4.914 \\
\hline EARN & 0.613 & 1.633 \\
\hline
\end{tabular}

a. Dependent Variable: NormPost.pri

\subsection{Multiple Regression Analysis}

A multiple regression test was performed to predict the share market price from a number of variables, namely INCA, 
FNCA, IVNCA, CA, TL and EARN. The regression results were presented in Table 7A and Table 7B.

Table 7A. Multiple linear regressions (pre adoption period of FRS 138)

\begin{tabular}{llll}
\hline Variables & Coefficient (Beta) & t-statistics & p-value \\
\hline INCA & 0.134 & 2.391 & 0.019 \\
\hline FNCA & 0.265 & 3.509 & 0.001 \\
\hline IVNCA & 0.055 & 1.011 & 0.314 \\
\hline CA & 0.319 & 3.744 & 0.000 \\
\hline TL & -0.062 & -0.638 & 0.525 \\
\hline EARN & 0.422 & 6.658 & 0.000 \\
\hline (Constant) & & -2.750 & 0.007 \\
\hline R & 0.864 & & \\
\hline R square & 0.746 & & \\
\hline Adj R square & 0.732 & & \\
\hline F change & 51.954 & & \\
\hline
\end{tabular}

* significant at $\mathrm{p}<\overline{0.05}$

The coefficient of determination (Adjusted $\mathrm{R}^{2}$ ) was 0.732 (Table 7A) which meant that $73.2 \%$ of the change in DV share market price (variable P)) was determined by the IV (variable INCA, FNCA, IVNCA, CA, TL and EARN). These also proved that the effect of INCA, FNCA, IVNCA, CA, TL and EARN as a whole on share market price was high. The regression results revealed that there was a positive significant relationship between the variable INCA and variable $\mathrm{P}(\mathrm{t}$ statistic $=2.391 ; \mathrm{p}$ value $=0.019$ ). The positive relationship has been indicated by a positive coefficient sign with the coefficient value of 0.134 . Results have indicated that the intangible assets are value relevant in the pre adoption period of FRS138, thus $\mathrm{H} 1$ is supported. The findings on other predictors such as FNCA $(\mathrm{t}$ statistics $=3.509, \mathrm{p}$ value $=0.001), \mathrm{CA}(\mathrm{t}$ statistics $=3.744, \mathrm{p}$ value $=0.000)$ and $\mathrm{EARN}(\mathrm{t}$ statistics $=6.658, \mathrm{p}$ value $=0.000$ ) were found to be significant and positively related to share market price (variable P), except for TL ( $t$ statistic $=-0.638, \mathrm{p}$ value $=0.525$ ) which has been found to be insignificant and negatively related to share market price (variable $\mathrm{P}$ ). IVNCA, however was found to have no significance in the relationship with share market price ( $\mathrm{t}$ statistic $=1.011 ; \mathrm{p}$ value $=0.134)$.

Table 7B. Multiple linear regressions (post adoption period of FRS 138)

\begin{tabular}{|c|c|c|c|}
\hline Variables & Coefficient (Beta) & t-statistics & p-value \\
\hline INCA & -0.028 & -0.427 & 0.670 \\
\hline FNCA & 0.387 & 3.751 & 0.000 \\
\hline IVNCA & 0.051 & 0.740 & 0.461 \\
\hline $\mathrm{CA}$ & 0.398 & 3.917 & 0.000 \\
\hline TL & -0.188 & -1.369 & 0.174 \\
\hline EARN & 0.388 & 4.890 & 0.000 \\
\hline (Constant) & & -1.791 & 0.076 \\
\hline $\mathrm{R}$ & 0.77 & & \\
\hline R square & 0.592 & & \\
\hline Adj R square & 0.569 & & \\
\hline F change & 25.650 & & \\
\hline
\end{tabular}

Table 7B has presented that the coefficient of determination (Adjusted $\mathrm{R}^{2}$ ) was 0.569 , meaning that $56.9 \%$ of the 
change in dependent variable (share market price (variable P)) was determined by the independent variables (variable INCA, FVCA, IVNCA, CA, TL and EARN). These also mean that the effect of INCA, FVCA, IVNCA, CA, TL and EARN as a whole on share market price was moderately high. The coefficient of intangible assets was 0.134 in the pre adoption period of FRS 138 and it has reduced to -0.028 during the post adoption period of FRS 138. The regression results have also revealed that there was no significant relationship between the intangible asset (variable INCA) and share market price (variable P) (t statistic $=0.427 ; \mathrm{p}$ value $=0.670$ ). The results indicated that the intangible assets are not value relevant during during the post adoption period of FRS 138, thus H2 was not supported. An important finding from the study was that the value relevance of the intangible asset (variable INCA) has decreased after adoption of IFRS. The findings in this study were consistent with Barzegari's (2011) research where the study has suggest that accounting information value relevancy in UAE has decreased post reform in accounting standards. Another finding that was consistent with these results was from X. D. Ji \& Lu (2014) in a study on value relevance and reliability of intangible asset on Australian companies before and after the adoption of IFRS. The study had found that the value relevance of intangible has declined in the post adoption period of IFRS. Another finding that was also consistent with this study was from Jermakowicz, Chen, \& Donker (2017) in their study to investigate the value relevance of IFRS adoption by comparing the association between accounting measures and market values under CGAAP and under IFRS for Canadian companies. The study has found that noncurrent asset and book value of equity are lower under IFRS than under CGAAP. Findings on other predictors have indicated that for FNCA, $t$ statistics is 3.751 and $p$ value is 0.000 . For CA, t statistics is 3.917 and $p$ value is 0.000 . For EARN, $t$ statistics is 4.890 and $p$ value is 0.000 . All were found to be significant and positively related to share market price (variable P). For IVNCA, $t$ statistics is 0.740 and $p$ value is 0.461 was found to be insignificant but positively related to share market price (variable P). For TL, however has been found to have no significance in the relationship with share market price where the $t$ statistic is -1.369 and $p$ value is 0.174 . It was noted that the results during post adoption period have shown that only $56.9 \%$ of change in dependent variable was determined or predicted by the independent variables. One possible reason was that due to the change in accounting standards, there was another unknown factor or another factor that has affected the relationship between independent variables towards share market price, hence influencing P. The "another factor" was not investigated in this study and this can be explored in future research.

\subsection{Summary of Hypothesis Results}

This study shows that there is a relationship between P and INCA, FNCA, IVNCA, CA, TL and EARN. Results from this study have indicated that during pre adoption period of FRS 138, 73.2\% of the change in dependent variable (variable P) was determined by the independent variables compared to post adoption period of FRS 138, whereby only $56.9 \%$ variance was explained. In terms of relevancy of intangible assets, results have indicated that intangible assets are value relevant during the pre adoption period of FRS 138 hence hypothesis 1 (H1) is supported. On the other hand, intangible assets are not value relevant during the post adoption period of FRS 138 hence hypothesis $2(\mathrm{H} 2)$ is not supported.

\section{Conclusion}

This study objective is to examine the value relevance of reported intangible assets in Malaysia before and after the adoption of FRS 138. Two research questions have been identified in this study. First, is to find out has the value relevance of intangible asset changed after IFRS has been adopted? Second, to find out is there a significant relationship between value relevance of intangible asset with firm's performance during pre adoption period of IFRS?. This study covers a period of eight years whereby the years have been split into four years of pre adoption period (year 2002 to 2005) and another four years of post adoption period (year 2008 to 2011). This study has excluded two years, which is year 2006 and year 2007 for the transitional of the adoption of FRS 138 in Malaysia to take effect, that is, the standard is applies to companies having yearly reporting period beginning on 1 January 2006 or after 1 January 2006. Hypotheses were developed to answer the research question. As such, the first hypothesis to find out whether value relevance of intangible asset has significant relationship with firms performance during the pre adoption period of FRS 138 (H1). Findings have showed that the value relevance of intangible assets has a significant relationship with firm's performance during pre adoption period of FRS 138, thus hypothesis 1 is supported. This finding answers the second research question on whether is there any significant relationship between value relevance on intangible asset with firm's performance.

The second hypothesis is to find out whether value relevance of intangible asset has significant relationship with firms performance during the post adoption period of FRS 138 (H2). Findings have showed that the value relevance of intangible assets has no significant relationship with firm's performance during post adoption of FRS 138, thus 
hypothesis 2 is not supported. Results from the second hypothesis have showed that the value relevance of intangible asset has declined since the adoption of FRS 138. This finding answers the first research question on whether the value relevance of intangible asset changed after IFRS have been adopted. From the results of this study, it seems that the trend of value relevance on the reported intangible asset have decreased post adoption period of FRS 138 in Malaysia. Results also showed that the intangible assets are not value relevant during post adoption period of FRS 138 in Malaysia. This study hopes that the results presented in this paper able to contribute to the existing literature on the issue of intangible asset and its value relevance, specifically for Malaysian companies. This study also hopes to be able to give an indication on the FRSs impact.

This study had a limitation whereby this study only focuses on the intangible intensive companies listed in Bursa Malaysia where some of the sectors have only minimum numbers of companies, for example the technology sector. It can be seen that this study is heavily concentrated in two industry sector that is Trading Services and Industrial Product. Results of this study might be different if more companies from other sectors are used. Another limitation of this study is because of the relatively low ratio of sample to initial population after going through the data elimination process. This relatively low sample size compared to the population limits generalisability and the this study empirical analysis (Jermakowicz et al., 2017)

The results of this study have shown that during the post adoption period of FRS138, there is another factor that affects the relationship between share market price and intangible noncurrent asset, fixed asset or property, plant and equipment, investment, current asset, total liabilities, and earnings. Future study can be done to investigate the additional factors or variables that affect this relationship and gave influence to the share market price.

\section{References}

Abdul-Shukor, Z., Ibrahim, M., \& Kaur, J. (2008). The value relevance of intangibles non-Current assets in different economic conditions. International Review of Business Research Papers, 4(2), 316-337. http://doi.org/10.1080/14613800902924474

Abubakar, S. (2015). Intangible Assets and Value Relevance of Accounting Information of Listed High-Tech Firms in Nigeria. Research Journal of Finance and Accounting, 6(11), 60-79.

Adesegun, O., \& Ayenakin, O. (2015). Insecurity and Foreign Direct Investment in Nigeria. International Journal of Sustainable Development \& World Policy, 4(4), 56-68. https://doi.org/10.18488/journal.26/2015.4.4/26.4.56.68

Almeqdadi, F. (2018). The Effects of Using an Interactive Software (GSP) on UAE Students' Attitudes towards Geometry. American Journal of Social Sciences and Humanities, 3(1), 22-28. https://doi.org/10.20448/801.31.22.28

Aremu, J. O., \& Ediagbonya, M. (2018). Trade and Religion in British-Benin Relations, 1553-1897. Global Journal of Social Sciences Studies, 4(2), 78-90. https://doi.org/10.20448/807.4.2.78.90

Barzegari, K. (2011). Value- Relevance of Accounting Information in the United Arab Emirates. International Journal of Economics and Financial Issues, 1(2), 33-45.

Bhatia, A., \& Aggarwal, K. (2018). Impact of investment in intangible assets on corporate performance in India. International Journal of Law and Management, 60(2). https://doi.org/10.1108/IJLMA-05-2017-0127

Chalmers, K., \& Godfrey, J. (2006). Intangible Assets: Diversity of Practices and Potential Impacts from AIFRS Adoption. Australian Accounting Review, 16(40), 60-71. https://doi.org/10.1111/j.1835-2561.2006.tb00046.x

Chidoko, C. (2014). Labor and Economic Growth in Zimbabwe. The Economics and Finance Letters, 1(4), 24-29. https://doi.org/10.18488/journal.29/2014.1.4/29.4.24.29

Ciprian, G. G., Valentin, R., Mădălina, G. (Iancu) A., \& Lucia, V. (Vlad) M. (2012). From Visible to Hidden Intangible Assets. Procedia - Social and Behavioral Sciences, 62, 682-688. https://doi.org/10.1016/j.sbspro.2012.09.116

Company, P., Jensen, C., \& Meckling, H. (1976). Theory of the Firm: Managerial Behavior, Agency Costs and Ownership Structure. Journal of Financial Economics, 3(4), 305-360. https://doi.org/10.1016/0304-405X(76)90026-X

Easton, P. D., Eddey, P. H., \& Harris, T. S. (1993). An Investigation of Revaluations of Tangible Long-Lived Assets. Journal of Accounting Research, 31, 1-38. https://doi.org/10.2307/2491161

Edeme, R. K. (2018). Revisiting the Economic Growth-Welfare Linkages: Empirical Evidence from Nigeria. Asian Themes in Social Sciences Research, 1(1), 28-33. https://doi.org/10.33094/journal.139.2018.11.28.33 
Ekpung, E. G. (2014). Public infrastructure spending and economic growth in Nigeria: An Error Correction Mechanism (ECM) approach. Journal of Social Economics Research, 1(7), 129-140.

Fitriandi, P., Kakinaka, M., \& Kotani, K. (2014). Foreign direct investment and infrastructure development in Indonesia: Evidence from province level data. Asian Journal of Empirical Research, 4(1), 79-94.

Gamayuni, R. R. (2015). The Effect of Intangible Asset, Financial Performance and Financial Policies on the Firm Value. International Journal of Scientific \& Technology Research, 4(1), 202-212.

Haji, A. A., \& Ghazali, N. A. M. (2018). The role of intangible assets and liabilities in firm performance: Empirical evidence. Journal of Applied Accounting Research, 19(1), 42-59. http://doi.org/10.1108/JAAR-12-2015-0108

Hawamdeh, G. (2018). Countering the Crimes of Administrative Corruption in the International Law. International Journal of Asian Social Science, 8(9), 751-769. https://doi.org/10.18488/journal.1.2018.89.751.769

Ibrahim, P., \& Ali, M. (2014). Foreign Direct Investment Affluences in Iskandar Malaysia. International Journal of Management and Sustainability, 3(2), 72-83.

Istrate, R. (2013). IFRS adoption and the value relevance of goodwill and other intangible assets: U. K. empirical evidence. University Of Amsterdam.

Jaafar, H., \& Halim, H. A. (2013). Firm Life Cycle and the Value Relevance of Intangible Assets: The Impact of FRS 138 Adoption. International Journal of Trade, Economics and Finance, 4(5), 252-258. http://doi.org/10.7763/IJTEF.2013.V4.296

Jermakowicz, E. K., Chen, C., \& Donker, H. (2017). Financial statement effects of adopting IFRS : the Canadian experience Professor of Accounting Tennessee State University College of Business and Public Policy.

Jerzemowska, M. (2006). The Main Agency Problems and Their Consequences. Acta Oeconomica Pragensia, 14(3), 9-17. https://doi.org/10.18267/j.aop.73

Ji, X. D., \& Lu, W. (2014). The value relevance and reliability of intangible assets Evidence from Australia before and after adopting IFRS. Asian Review of Accounting, 22(3), 182-216. http://doi.org/10.1108/ARA-10-2013-0064

Kargin, S. (2013). The Impact of IFRS on the Value Relevance of Accounting Information: Evidence from Turkish Firms. International Journal of Economics and Finance, 5(4), 71-80. http://doi.org/10.5539/ijef.v5n4p71

Kasasbeh, H. A., Mdanat, M. F., \& Khasawneh, R. (2018). Corruption and FDI Inflows: Evidence from a Small Developing Economy. Asian Economic and Financial Review, 8(8), 1075-1085. https://doi.org/10.18488/journal.aefr.2018.88.1075.1085

Khemili, H., \& Belloumi, M. (2018). Cointegration Relationship between Growth, Inequality and Poverty in Tunisia. International Journal of Applied Economics, Finance and Accounting, 2(1), 8-18. https://doi.org/10.33094/8.2017.2018.21.8.18

Krstić, J., \& Đorđević, M. (2010). FINANCIAL REPORTING ON INTANGIBLE ASSETS - Jovan Krstić, Milica Đorđević. Economics and Organization, 7(3), 335-348.

Matolcsy, Z., Stokes, D., \& Wells, P. (2002). Valuing intangible assets provides new challenges. JASSA, 1, 1-8. Retrieved from https://opus.lib.uts.edu.au/bitstream/10453/963/3/2002000444.pdf

Mokuolu, J. O. (2018). Assessment of the Development and Growth of Nigerian Economy as a Function of FDI Flows. Journal of Accounting, Business and Finance Research, 2(2), 91-97. https://doi.org/10.20448/2002.22.91.97

Morris, R. D. (1987). Signalling, Agency Theory and Accounting Policy Choice. Accounting and Business Research, 18(69), 47. https://doi.org/10.1080/00014788.1987.9729347

Okafor, C., \& Shaibu, I. (2016). Modelling Economic Growth Function in Nigeria: An ARDL Approach. Asian Journal of Economics and Empirical Research, 3(1), 84-93. https://doi.org/10.20448/journal.501/2016.3.1/501.1.84.93

Okon, E. O., \& Monday, O. I. (2017). Empirical and Evidence-Based Investigation: External Debt, Poverty and Economic Growth Nexus. International Journal of Applied Economics, Finance and Accounting, 1(1), 37-47. https://doi.org/10.33094/8.2017.11.37.47

Okoye, J. C. (2014). Anti-corruption crusade in Nigeria: More words than deeds. International Journal of Public 
Policy and Administration Research, 1(2), 47-63.

Pallant, J. (2007). SPSS Survival Manual (3rd ed.). Australia: McGraw-Hill Education.

Ruiwen, Z., \& Honghui, G. (2010). An Empirical Test of the Impact of Intangible Assets on Enterprise Performance of Chinese Social Services Listed Companies, pp. 1373-1377. Retrieved from http://apps.isiknowledge.com/full_record.do?product=UA\&search_mode=GeneralSearch\&qid=8\&SID=3DWK ALzBkiGRiUyBLFg\&page $=2 \&$ doc $=71$

Sarwar, N., \& Mubarik, M. S. (2014). Foreign Direct Investment (FDI) and Employment: A Case of Province of Punjab, Pakistan. The Economics and Finance Letters, 1(4), 59-65. https://doi.org/10.18488/journal.29/2014.1.4/29.4.59.65

Setiyawati, H., Iskandar, D., \& Basar, Y. S. (2018). The Quality of Financial Reporting through Increasing the Competence of Internal Accountants and Accrual Basis. International Journal of Economics, Business and Management Studies, 5(1), 31-40. https://doi.org/10.20448/802.51.31.39

Shukor, Z. A., Ibrahim, M. K., Kaur, J., \& Nor, H. M. (2009). The Value Relevance of Intangible Non-Current Assets during Different Economic Conditions and Accounting Environments. Malaysian Accounting Review, 8(2), 43-66. http://doi.org/10.1080/14613800902924474

Spence, M. (1973). Job Market Signaling. The Quarterly Journal of Economics, 87(3), 355-374. https://doi.org/10.2307/1882010

Templeton, G. F., \& Templeton, G. F. (2011). A Two-Step Approach for Transforming Continuous Variables to Normal_Implications and Recommendations for IS Research. Communications of the AIS, 28, 42-58. http://doi.org/10.17705/1CAIS.02804

Widiantoro, D. M. (2012). Measuring the Impact of Intangible Asset Investment Toward Company Financial Health and Company Agency Problem: Empirical Research from Indonesian. Journal of Finance and Risk Perspectives, 1(2), 1-24. Retrieved from http://papers.ssrn.com/sol3/papers.cfm?abstract_id=2078900

Wilson, A., David, U., Mary, O., \& Beatrice, E. (2014). How Telecommunication Development Aids Economic Growth: Evidence from Itu Ict Development Index (IDI) Top Five Countries for African Region. International Journal of Business, Economics and Management, 1(2), 16-28.

Yu-Chi, S., \& Lin, H. P. (2018). Causality Relationship between Tourism, Foreign Direct Investment and Economic Growth in Taiwan. Asian Journal of Economic Modelling, 6(3), 287-293.

Zhang, W. B. (2018). Endogenous Economic Growth with Education Subsidies. International Journal of Emerging Trends in Social Sciences, 2(1), 10-16. https://doi.org/10.20448/2001.21.10.16 